\title{
O HOSPITAL DAS CLÍNICAS DA FACULDADE DE MEDICINA DE RIBEIRÃO PRETO E A UNIVERSIDADE DE SÃO PAULO: SÃO ASSOCIADOS ?
}

\author{
THE H.C. OF THE F.M.R.P. AND THE U.S.P.: ARE THEY ASSOCIATED ?
}

Harley E. A. Bicas

Chefe do Departamento de Oftalmologia e Otorrinolaringologia da Faculdade de Medicina de Ribeirão Preto da Universidade de São Paulo e Presidente da Associação dos Docentes do Hospital das Clínicas da F.M.R.P.U.S.P., Ribeirão Preto - SP - Brasil.

E logo, como se o bem e o mal pudessem ser separados por uma palavra mágica, ela apareceu: "excepcionalidade". Ela justificaria a fina qualidade de certos docentes da Universidade de São Paulo para que se tornassem dignos de exercer assessorias; como, por exemplo, as que vários Departamentos da Faculdade de Medicina de Ribeirão Preto prestam ao seu respectivo Hospital das Clínicas. Ela teria aquela rara primazia de segregar o serviço de um docente ("seu desempenho acadêmico não é excepcional") enquanto o elogiaria ("ainda que muito bom") o que, certamente, consolaria os assim discriminados. E, no reino dos contentes, todos seriam felizes para sempre.

Claro que não é assim tão simples. Inicialmente trazida a uma exegese (pois certamente necessária, tão graves suas implicações) e ainda mais porque ficam sérias desconfianças de que "excepcionalidade" só traduz um resultado no julgamento de quem opera o instrumento, as dificuldades logo aparecem. De qualquer modo, a primeira análise, e reflexão, mostra que o significado do termo é, mesmo, discriminatório, dando ênfase a uma diferença qualitativa: extraordinário, incomum, excêntrico, fora da regra, etc. Perigoso! Pois, numa curva de normalidade, as exceções gaussianas são de dois tipos antagônicos: uma "excelente", outra "execrável". E, obviamente dentro da mais pura lógica, pode-se considerar que, para o exercício de uma atividade, excepcionalidade tanto se aplica ao que a exerce com maestria (excelência) como ao que demonstra pouca competência para ela. Claro, também, que, embora pareça ambíguo, ligar excepcionalidade ao exercício esperado dessa atividade é justificável nos dois casos: no primeiro, como prêmio, no segundo, como forma de correção de um desequilíbrio, incentivando a que se desenvolva a capacitação deficiente. Mas, embora tocantemente humana e, até, com reflexos pedagógicos e de interesse universitário, não se pode acreditar que a catalogação de excepcionalidade tenha este sentido de aplicação na instituição. Daqui para diante suponhase, pois, a classificação como sinônima de excelência e instrumento de reconhecimento de uma aptidão, o que contribuiria para diminuir, pelo menos um pouco, a polêmica originada da aplicação desse conceito. Pois, em vários casos, argumenta-se, o critério da tal excepcionalidade parece ter sido aplicado com aqueles objetivos de edificação pessoal, não com o de reconhecimento de uma aptidão.

O segundo aspecto de cogitação é o da representação quantitativa do que seja excelência, num grupo. E aqui se volta, naturalmente, ao referencial, à relativização do corte: uma vez ele definido, pode ser que os critérios sejam tão rígidos que ninguém os atinja; ou, ao contrário, tão permissivos, que todos por eles passem. De uma forma ou de outra, seja para que cem, ou vinte ou dois por cento de um grupo atinja (ou não) um certo nível, arbitrado, o referencial divisório tem que ser equânime, objetivo, recorrente e, principalmente, conhecido, para que seja coletivamente válido, subjetivamente aceito e eventualmente recorrível. E jamais pode ser elemento de surpresa que todos os participantes de um grupo alcancem um critério (por exemplo, o de excelência em determinado desempenho) mormente quando a própria seleção pela qual são cooptados assim os requer.

Finalmente, o terceiro ponto é o da aplicação do conceito: para que se o deseja ? Várias hipóteses serão formuláveis, visto que as consequiências atin- 
gem tanto a docentes sobre os quais se dirigem, quanto a própria instituição, cujas assessorias estão sendo "permitidas". Mas, partindo-se do pressuposto de que se pretende premiar o docente e de que as atividades de assessoria requeridas sejam claramente definidas, elas ficam reduzidas a duas.

a) Uma possibilidade é a de os critérios de excelência não serem os mais oportunos para o desempenho da função requerida. Em outras palavras, estimular-se-ia um tipo de atividade por meio de indicações para uma outra, não necessariamente bem exercitada ou desejada. (Retorna-se, por outro caminho, à condição de "incentivo ao equilíbrio dos desempenhos".) O docente fica dividido e o receptor da assessoria fica onerado. Como se trata do H.C., braço operacional do ensino clínico da F.M.R.P. e suporte de boa parte de suas pesquisas, a hipótese deve ser descartada, por teleologicamente incoerente.

b) A outra possibilidade, a inicial, é a de que, para atender aos critérios de excelência, o bom desempenho das atividades, para as quais a assessoria é concedida, não baste. Volta, novamente, o conceito de premiação a ser fundado no desempenho de "outras atividades", cujo exercício é certamente importante, mas não necessariamente indispensável para o ensino da prática médica. Curiosamente, a hipótese também retorna ao conceito de "equilíbrio nos desempenhos" para o merecimento da "excelência", agora não mais incentivado, mas finalmente reconhecido.

Penso que na raiz do problema, reste a sutileza da diferença de aspirações entre o que a Universida- de de São Paulo pretende como critério de excelência para seus docentes (supostamente, porque ainda não claramente estabelecido, o de "equilíbrio no desempenho das atividades") e o que o Hospital das Clínicas requer (o ótimo desempenho em uma das funções acadêmicas em Medicina), qual seja, o de excelência no exercício da atividade médica em ambulatórios, salas cirúrgicas e laboratórios de seus apoios (aliás, base do próprio ensino, a razão última de uma Faculdade, qualquer que ela seja). E por se tratar de uma questão de "princípios", nunca se chegaria a um acordo entre as partes, não fossem elas intimamente ligadas.

É absolutamente justo que a Universidade formule seus critérios. Também seja admitido que nem tudo o que é bom para o Hospital será bom para a Universidade e vice-versa; mas, basicamente, a maioria do que é bom para o Hospital é bom para a Universidade e vice-versa. Daí a urgência de que as instituições se entendam, pois a empreitada delas deve ser a mesma. Há um temor real de que uma visão universitária de "universalidade" de desempenhos acadêmicos, se não apropriadamente modulada, ou aferida, não seja "hospitaleira" ao ensino médico de excelência.

Convém uma claríssima exposição de quais sejam os critérios para as avaliações e de como as "excelências" sejam alcançáveis. Então, talvez, discussões paralelas sobre o artigo 51 do Estatuto da U.S.P., pelo qual "O departamento é a menor fração da estrutura universitária para os efeitos de organização didático-científica e administrativa" (que, então, responderia pelo equilíbrio de desempenhos) percam a razão de ser. 